\title{
Clinical and Radiographic Evaluation of Rehabilitated Implants with Overdenture with Two Ball Abutments in the Mandible and Submitted to Immediate Load: One Year of Observation
}

\author{
Evaluación Clínica y Radiográfica de Implantes Rehabilitados con Sobredentadura con \\ dos Pilares de Bola en la Mandíbula y Sometidos a Carga Inmediata: Un Año de Observación
}

Juan Alberto Aristizabal Hoyos'; Juan Gabriel Burbano Luna²; Alicia Sandoval Reyes²; José Julián Ramírez Torres²; Paula Tatiana Chacón Arboleda3; Santiago González Ossa ${ }^{4}$ \& Carlos Eduardo Arango Gonzalez ${ }^{5}$

ARISTIZABAL, H. J. A.; BURBANO, L. J. G.; SANDOVAL, R. A.; RAMÍREZ, T. J. J.; CHACÓN, A. P. T.; GONZÁLEZ, O. S. \& ARANGO, G. C. E. Clinical and radiographic evaluation of rehabilitated implants with overdenture with two ball abutments in the mandible and submitted to immediate load: One year of observation. Int. J. Odontostomat., 11(4):451-459, 2017.

ABSTRACT: The purpose of this prospective clinical study was to evaluate the clinical and radiographic survival of two non-splinted implants immediately loaded with ball abutments for supporting mandibular overdentures. Thirty edentulous patients using full dentures (22 women and 8 men) with a mean age of 64 years were included in this study. Each patient received two inter-foraminal implants in the mandible, near the canine, with an insertion torque greater than $45 \mathrm{Ncm}$. Nonsplinted ball abutments were connected to the implants, and the overdenture was immediately loaded. The success of the implants was clinically and radiographically evaluated; along with the satisfaction level of the patients, after the first year of having placed the implants. One patient withdrew from the study. After 12 months the implants were loaded, the survival rate was of $98.27 \%$, one implant failed. The average bone loss was of $0.34 \mathrm{~mm}$. No surgical complications were observed, minor prosthetic maintenance appointments were required. The satisfaction of the patients was of $89.3 \%$. The immediate loading of two non-splinted implants in the inter-foraminal area of the mandible retaining an overdenture by means of ball abutments is a predictable treatment, with a high success rate of survival and a favorable response of the peri-implant tissues. The patients showed good satisfaction with this treatment modality.

KEY WORDS: immediate dental implant loading, denture, overlay, mouth rehabilitation.

\section{INTRODUCTION}

Consensus between McGill (2003) and York (Thomason et al., 2009), as well as a large body of scientific evidence, have suggested that two implants supporting a mandibular overdenture should be offered as the first option for the treatment of edentulous patients. The overdentures on implants in the mandible increases the satisfaction and the quality of life of the edentulous people (Awad et al., 2003; Stoker et al., 2007).
The possibility of a direct connection of the prosthesis to the osseointegrated dental implants, and the transmission of forces of the artificial teeth to the mandible, secures the retention and stability of the prosthesis, and decreases the trauma to the oral soft tissues. This allows patients to feel that their artificial teeth are an integral part of themselves, which increases their quality of life (Johns et al., 1990).

${ }^{1}$ Dentist, Oral Rehabilitation Practice, Autonoma University of Manizales, Colombia.

2 Dentist, Autonoma University of Manizales, Manizales, Colombia.

${ }^{3}$ Dentist, periodontal practice Autonoma University of Manizales, Manizales, Colombia.

${ }^{4}$ Dentist, Maxillofacial Surgery Practice Autonoma University of Manizales, Manizales, Colombia.

${ }^{5}$ Dentist, Oral Rehabilitation Practice Autonoma University of Manizales, Manizales, Colombia. 
When implants are used to support a removable overdenture, an optimum distribution of stress is desirable to minimize the forces on the implants and the denture movements (Tokuhisa et al., 2006). The types of abutments used for overdentures include bar systems, splinting the implants with different designs and individual adjustments as locator, balls, and magnetic adjustments (Feine et al., 2002). Consistent differences in the patients' satisfaction rate have not been reported regarding the type of adjustments used on muco-supported implant-retained dentures (Lachmann et al., 2007; Nogueira et al., 2009) or regarding the use of splinted or non-splinted modalities (van Kampen et al. 2003).

Different studies have concluded that twosplinted or non-splinted implants in the inter-foraminal region of the mandible are enough to support an overdenture (Mericske, 1990; Mericske \& Zarb, 1993; Feine \& Carlsson, 2003; Attard \& Zarb, 2004; Alfadda et al., 2009; Cehreli et al., 2010).

In a conventional protocol after the implant surgery, it is considered mandatory that the patient should not wear his/her prosthesis for 2-4 weeks (Albrektsson, 1983).

It has been suggested that the implantprosthesis connection is to be carried out after a critical scarring period, so the bone-implant osseo-integration is usually given a 3-month period for the mandible (Brånemark et al., 1985). Most patients perceive such period from the implant placement until the final rehabilitation, as traumatic and uncomfortable, as the provisional prosthesis compromise function, aesthetics and is not comfortable (Esposito et al., 2007).

Different authors (Babbush et al., 1986; Buser et al., 1988; Romeo et al., 2002) have shown the benefits of an immediate loading technique with four implants in the mandibular symphysis with an over denture. The implants are rigidly splint with a metal bar, after two or three days of their placement. The splinting of the immediately placed implants was advocated in order to avoid force peaks in the boneimplant interface during the healing period, thus improving the survival rate (Chiapasco \& Lazza 2002).

Prospective studies have reported survival rates between $94.4 \%$ and $100 \%$ for immediately loaded and splinted implants in observation periods between 12 and 96 months (Gatti et al., 2000; Stricker et al., 2004; Degidi \& Piatelli, 2005).
For a long time, the immediate loading with less than four implants had been considered harmful for osseo-integration. However, more recent researches are showing positive results regarding the possibility of immediately loading of the overdentures on one (Liddelow \& Henry, 2007; Liddelow \& Henry, 2010) or two non-splinted, inter-foraminal implants (Turkyilmaz et al., 2006; Kawai \& Taylor 2007; Marzola et al., 2007; Kronstrom et al., 2010; Liao et al., 2010; Roe et al., 2011; Elsyad et al., 2012; Grandi et al., 2012; Lahori et al., 2012; Shayegh et al., 2012; Turkyilmaz et al., 2012).

The immediate loading of the implants has been considered, since it has many advantages: a minor surgical procedure (Hobo et al., 1989), is substantially less expensive (Heydence et al., 1989), the immediate restoration of aesthetics and function, decreased number of visits of the patient for treatment, reduced morbidity of a second surgical intervention (Roe et al., 2010) and good levels of patients satisfaction.

A recent meta-analysis (Schimmel et al., 2014) regarding the loading protocols for mandibular overdentures conclude that although the three loading protocols (Immediate, early, conventional) provide a high rate of survival, the protocols of early and conventional loading are better documented than the protocol for immediate loading, therefore, further knowledge would be required regarding this aspect. The purpose of this study was to evaluate clinically and radiographically the behavior of two non-splinted implants with ball-type abutments rehabilitated with overdentures, in the mandible and loaded immediately after one year of function in the mouth.

\section{MATERIAL AND METHOD}

Selection of Patients: Thirty bimaxillary edentulous patients using full prosthesis with a mean age of 64 years, 22 women and 8 men were included in this study. In order to be included, they should have osseous availability to allow the placement of two inter-foraminal implants of $3.8 \times 15$ or $3.8 \times 12 \mathrm{~mm}$. The patients excluded were those who had received previous mandibular bone regeneration, heavy bruxers, irradiated patients, patients with mental disorders, with severe systemic disease that prevented surgery, patients who received injectable bisphosphonates, and heavy smokers.

The research was approved by the Bioethics Committee (Act 12 of 2010), and informed consent was 
ARISTIZABAL, H. J. A.; BURBANO, L. J. G.; SANDOVAL, R. A.; RAMíREZ, T. J. J.; CHACÓN, A. P. T.; GONZÁLEZ, O. S. \& ARANGO, G. C. E. Clinical and radiographic evaluation of rehabilitated implants with overdenture with two ball abutments in the mandible and submitted to immediate load: One year of observation. Int. J. Odontostomat., 11(4):451-459, 2017.

requested for all patients according to Resolution 8430 of the Ministry of Health of Colombia.

Surgical procedure: Antibiotic prophylaxis was prescribed with $2 \mathrm{~g}$ of amoxicillin, 1 hour before the surgical procedure. All surgeries were carried out by the same surgeon. Two implants (BIOHORIZONS TAPERED INTERNAL IMPLANT SYSTEM) of $3.8 \mathrm{x}$ 15 or $3.8 \times 12 \mathrm{~mm}$, with prosthetic platform of 3.5 and hexagonal internal connection were inter-foraminally inserted under local anesthesia (2\% lidocaine with epinephrine, Ropsohn therapeutics inc.). A crestal incision was made, a flap was raised at total thickness, involving only the lingual portion to reduce post-surgical edema in the passage area and to allow surgical access to the lingual surface of the mandible. The bone was prepared using systematic drilling with abundant irrigation (with the surgical kit of internal connection Biohorizons ${ }^{\circledR}$ ) using the $3.2 \mathrm{~mm}$ diameter drill as the final drilling and with the desired depth). The operator used parallel straight pins between drill and drill, in order to avoid distortion of parallelism required for the overdentures system. The implant with the surgical unit with maximum insertion torque of $45 \mathrm{Nm}$ was placed, however, the final torque was achieved with manual rachet until the implant was at crestal level. The position of the implant was performed by means of analyzing a panoramic radiography with a radiographic/surgical guide based on the duplicate of the existing full denture. After the insertion of the implant, the ball abutments were connected.

Prosthetic treatment: All prostheses were created by an only prosthodontist. The ball abutments were torqued at $20 \mathrm{Ncm}$. The prostheses were flared to create the space for the abutments and in the vestibular side, two holes were done to allow the visualization of adequate space and without interferences. Once the passive seating of the prosthesis was achieved, the capturing of the housings or retentive attachments (Biohorizons) in the oral cavity with self-curing acrylic (Kooliner) was performed.

Two circular portions of sterile rubber dam over the ball abutments were placed to avoid undesirable acrylic retentions. Afterwards, the occlusion was checked.

As postoperative measures, patients were asked to continue for additional seven days under antibiotic therapy, not removing the prosthesis in a week, following soft diet, and doing mouthwashes with chlorhexidine solution $0.12 \%$ (Clorhexol, FarPag) twice a day for one minute during 14 days. The pain was controlled with acetaminophen $500 \mathrm{mg}$, one every 8 hours during three days, Nimesulide $100 \mathrm{mg}$, one every 12 hours during three days. Soft diet was recommended during the first weeks.

Follow-up visits: Weekly clinical controls were performed during the first month, and at 2, 3, 6, and 12 months. Periapical and panoramic radiographs were taken as a baseline for the third week after the surgery. One year after surgery, a new clinical and radiographic control was performed. From this control, the results for this research were obtained.

\section{Evaluation: During the controls, it was observed:}

Survival of the implants: The success criteria of Ahlqvist et al. (1990) were taken into account: the implant should be functioning and clinically stable, there should be no pain, peri-implant tissues should be clinically healthy or show signs of mild inflammation; $\mathrm{X}$-rays should not show radiolucency or other pathological conditions adjacent to the implant.

Changes in the bone level: The changes in the bone level were measured by means of periapical $x$-ray with the standardized technique of parallelism. A calibrated examiner performed the measurement of the bone height, Image Analysis software (Sopro Imagin) was used to measure the distance between the implant platform and the most apical bone level in contact with the implant body, at mesial and distal level. The distortion of each X-ray was calculated, taking into account the length of the implant in position.

A calibrated examiner performed the measurements, first, at the third week, and then, one year after the implants' placement, with the difference between them and the average loss for all the implants was calculated.

Comparative measurements were performed with another calibrated examiner in a different university in order to confirm the results.

Evaluation of the peri-implant conditions: Depth assessment to the probing in millimeters, plaque index, bleeding index, and presence of calculus was included. The plaque and bleeding were evaluated according to the indexes of Mombelli \& Lang (1994). For the plaque: 0 : When plaque 1 is not detected: The bacterial plaque is detected only by passing the periodontal probe through the marginal surface of the implant, 2: The 
ARISTIZABAL, H. J. A.; BURBANO, L. J. G.; SANDOVAL, R. A.; RAMíREZ, T. J. J.; CHACÓN, A. P. T.; GONZÁLEZ, O. S. \& ARANGO, G. C. E. Clinical and radiographic evaluation of rehabilitated implants with overdenture with two ball abutments in the mandible and submitted to immediate load: One year of observation. Int. J. Odontostomat., 11(4):451-459, 2017.

bacterial plaque is visible, 3: Abundant bacterial plaque. For bleeding index 0 : No bleeding on tour with the probe, 1: Bleeding in isolated points, 2: In line bleeding around the mucosa of the implant margin 3: Profuse bleeding (46). The probing depth was defined as an average value of measurements of 4 sites (mesial, distal, oral and lingual) using a calibrated periodontal probe (Hu-Fryde). The presence 1, or the absence 2 of dental calculus was also measured.

Prosthetic aspects: It was assessed if the overdenture retention, stability, static and dynamic occlusion, presence of fissures and fractures, as well as the state of the retentive elements were intact and fulfilled its retention function and need of relines.

Level of Satisfaction: Patient satisfaction was assessed using the survey validated by Bergendal \& Engquist (1998), through the use of questionnaires and a quantitative scale about the treatment.

Statistical Analysis: The patients and implants data were recorded in the statistical program SPSS version 19. Descriptive statistics, absolute and relative frequencies of each variable, averages, percentage and distribution among the sample were used to analyze the information.

\section{RESULTS}

The initial sample consisted of thirty patients with an average age of 64 years. 60 implants were placed in the mandible to support 30 immediately loaded overdentures. Each patient received two interforaminal implants, approximately, at the canine position. One patient was excluded from the research, since it was impossible to conduct assessments because he moved his permanent residence abroad.

Survival of the Implants: The survival rate after 1 year of function was of $98.27 \%$. One of the implants failed. Later, it was placed back and the implant immediately loaded. However, this patient was not taken into account for the study. (Table I).

The bone loss in the first year was averaged $0.34 \mathrm{~mm}$. (Table II). The distribution of the bone level changes is reported in Table III.

Peri-implant assessment. $62.5 \%$ of the implants did not show bacterial plaque. $3.57 \%$ in the inspection showed abundant plaque (Table IV).

Table I. One-year survival rate of the implants.

\begin{tabular}{ccccc}
\hline Time & n patients & $\begin{array}{c}\text { n successful } \\
\text { implants }\end{array}$ & $\begin{array}{c}\mathrm{n} \text { failed } \\
\text { implants }\end{array}$ & Survival rate \\
\hline 0 months & 30 & 60 & & \\
12 months & 29 & 57 & 1 & $98.27 \%$ \\
\hline
\end{tabular}

Table II. One-year average peri-implant osseous loss.

\begin{tabular}{lccccc}
\hline & \multicolumn{2}{c}{ Right implant } & \multicolumn{2}{c}{ Left implant } & Patients average \\
& Mesial & Distal & Mesial & Distal & \\
\hline & 0.248 & 0.368 & 0.475 & 0.296 & \\
Implant average & 0.308 & & & 0.385 & 0.347 \\
\hline
\end{tabular}

Table III. One-year values of peri-implant osseous loss per loss.

\begin{tabular}{ccccccccc}
\hline & \multicolumn{4}{c}{ Right implant } & \multicolumn{3}{c}{ Left implant } \\
\hline \multicolumn{1}{c}{ Mesial } & \multicolumn{2}{c}{ Distal } & \multicolumn{2}{c}{ Mesial } & \multicolumn{2}{c}{ Distal } \\
\hline & $\mathrm{N}$ & $\%$ & $\mathrm{n}$ & $\%$ & $\mathrm{~N}$ & $\%$ & $\mathrm{n}$ & $\%$ \\
-0.5 & 22 & 78.57 & 22 & 78.57 & 18 & 64.29 & 23 & 82.14 \\
$0.5-1$ & 5 & 17.86 & 3 & 10.71 & 7 & 25.00 & 4 & 14.29 \\
$-1-1.5$ & 1 & 3.57 & 2 & 7.14 & 1 & 3.57 & 1 & 3.57 \\
$-1.5-2$ & & & 1 & 3.57 & 2 & 7.14 & & \\
-2 & & & & & & & & \\
\hline
\end{tabular}


ARISTIZABAL, H. J. A.; BURBANO, L. J. G.; SANDOVAL, R. A.; RAMÍREZ, T. J. J.; CHACóN, A. P. T.; GonZÁLEZ, O. S. \& ARANGO, G. C. E. Clinical and radiographic evaluation of rehabilitated implants with overdenture with two ball abutments in the mandible and submitted to immediate load: One year of observation. Int. J. Odontostomat., 11(4):451-459, 2017.

Regarding the bleeding index, $92.86 \%$ of the implants did not show bleeding. Instead, $1.79 \%$ showed bleeding around the mucosa of the implant margin (Table V).

The increase in the probing depth was seen in 4 of the 56 implants assessed. These values were related to problems such as screw loosening and ball-type pillars (Table VI).

Table IV. Presence of bacterial plaque.

\begin{tabular}{ccc}
\hline Plaque index. & Implants $\mathrm{n}$ & Percentage \\
\hline 0 & 35 & 62.5 \\
1 & 13 & 23.22 \\
2 & 6 & 10.71 \\
3 & 2 & 3.57 \\
\hline
\end{tabular}

Table V. Bleeding index.

\begin{tabular}{lll}
\hline Bleeding & \multicolumn{2}{c}{ Implants } \\
& $\mathrm{n}$ & $\%$ \\
\hline 0 & 52 & 92.86 \\
1 & 3 & 5.36 \\
2 & 1 & 1.79 \\
3 & & \\
\hline
\end{tabular}

Table VI. Increased probing.

\begin{tabular}{lll}
\hline Increased probing & \multicolumn{2}{l}{ Implants } \\
& $\mathrm{n}$ & $\%$ \\
\hline Yes & 4 & 7.1 \\
No & 52 & 92.9 \\
\hline
\end{tabular}

Table VII. One-year prosthetic assessment.

\begin{tabular}{llllr}
\hline & Yes & \multicolumn{3}{l}{ No } \\
& $\mathrm{n}$ & $\%$ & $\mathrm{n}$ & $\%$ \\
\hline Active retention & 23 & 82.1 & 5 & 17.9 \\
Stay in place & 25 & 89.3 & 3 & 10.7 \\
Acceptable stability & 23 & 82.1 & 5 & 17.9 \\
Work when speaking & 25 & 89.3 & 3 & 10.7 \\
Static occlusion & 23 & 82.1 & 5 & 17.9 \\
Dynamic & 22 & 78.6 & 6 & 21.4 \\
Work when chewing & 23 & 82.1 & 5 & 17.9 \\
Presence of fissures & 1 & 3.6 & 27 & 96.4 \\
Presence of fractures & 1 & 3.6 & 27 & 96.4 \\
Intact retention elements & 16 & 57.1 & 12 & 42.9 \\
Functional elements & 23 & 82.1 & 5 & 17.9 \\
\hline
\end{tabular}

Prosthetic. The greater percentage of prostheses had active retention, remained in place, worked when speaking and chewing, and the static and dynamic occlusion was acceptable.

The retentive elements "O-ring" of the prosthetics were worn at $42.9 \% .17 .9 \%$ of them did not fulfill their function. One prosthesis was accidentally fractured. (Table VII)

Prosthetic complications. Prosthetic complications are described below in Table VIII. Fractures were not related to the functioning of the prosthesis, but to accidental rupture.

Satisfaction subjective assessment. This assessment was performed through the satisfaction survey applied to the annual control appointment. A satisfaction of $89.3 \%$ was found. The dissatisfaction of $10.7 \%$ in general was related to the lack of retention that prevented talking or chewing.

$100 \%$ considered their prosthesis as pretty (Table IX). On the subjective scale, the average was of 9.14 .

Table VIII. Prosthetic complications.

\begin{tabular}{lll} 
& $\mathrm{n}$ & $\%$ \\
\hline Loosening of the abutment & 2 & 3.57 \\
Fracture of the overdenture & 1 & 3.57 \\
Relines & 1 & 3.57 \\
Housing & 2 & 3.57 \\
O-ring wear & 1 & 42.85 \\
$\begin{array}{l}\text { Hyperplasia } \\
\text { Need to change housing due } \\
\text { to other procedures }\end{array}$ & 1 & 3.57 \\
\hline
\end{tabular}

Table IX. Percentage of patient satisfaction with the overdenture.

\begin{tabular}{lllll}
\hline & Yes & \multicolumn{3}{l}{ No } \\
& $\mathrm{n}$ & $\%$ & $\mathrm{n}$ & $\%$ \\
\hline Satisfied & 25 & 89.3 & 3 & 10.7 \\
It stays in place & 25 & 89.3 & 3 & 10.7 \\
It works when chewing & 24 & 85.7 & 4 & 14.3 \\
His/her prosthesis is pretty. & 28 & 100 & 0 & 0 \\
It works when speaking & 25 & 89.3 & 3 & 10.7 \\
\hline
\end{tabular}


ARISTIZABAL, H. J. A.; BURBANO, L. J. G.; SANDOVAL, R. A.; RAMíREZ, T. J. J.; CHACÓN, A. P. T.; GONZÁLEZ, O. S. \& ARANGO, G. C. E. Clinical and radiographic evaluation of rehabilitated implants with overdenture with two ball abutments in the mandible and submitted to immediate load: One year of observation. Int. J. Odontostomat., 11(4):451-459, 2017.

\section{DISCUSSION}

The implant survival in this study was $98.27 \%$ (57 of 58 implants observed at the first year of control). The bone loss at the first year was averaged 0.34 $\mathrm{mm}$. Turkyilmaz et al. (2006) reported success and implant survival of $100 \%$ and average of bone loss of $0.3 \pm 0.2 \mathrm{~mm}$. Marzola et al. observed $100 \%$ of success and implant survival, and the percentage for bone loss was $0.7 \mathrm{~mm}+/-0,5 \mathrm{~mm}$ after a year of observation. Konstrom et al. (2010) found that the implant survival was of $81.8 \%$ and the average of peri-implant bone loss was of $0.44 \pm 0.4 \mathrm{~mm}$. Liao et al. obtained an implant survival of $94 \%$, and when considering the loss on the smooth- and rough-surface of the implant, the average bone loss was of $0.73 \mathrm{~mm}$. At one year of observation, Roe et al. (2011) found a $100 \%$ survival and showed an average marginal bone change of $0.36+/-0.29 \mathrm{~mm}$. Elsyad et al. observed a $93 \%$ survival for immediate loading implants and found greater vertical loss in the group with immediate loading. Lahori et al. compared late loading and immediate loading and found no significant differences in either implant survival, or percentage of bone loss between the two groups. Shayegh et al. reported after 12 months of observation, an implant survival of $100 \%$ and average bone loss of $0.84+/-0.03 \mathrm{~mm}$. Grandi et al. observed a survival rate of $100 \%$ and a marginal bone loss of $0.298 \mathrm{~mm}$ after a year of observation.

When considering the success of an implant, several aspects must be taken into account, including the primary stability. It is believed that the primary stability of the implant plays an essential role in the success of the osseo-integration. The primary stability is given in function of the quality and quantity of the local bone, the geometry and the composition of the used implant and the implant placement technique (Meredith, 1998). A good primary stability of the implant after surgery has been highlighted as one of the most important clinical parameters when trying to succeed with immediate loading (Attard \& Zarb, 2005). A high torque in the implant placement is also associated with the primary stability (Marzola et al.). In this study, all implants were placed at more than $45 \mathrm{Ncm}$, which could be identified as one of the factors favoring the success. In contrast, Kronstrom et al. reported a $22 \%$ failure and insertion values between 30 and $40 \mathrm{Ncm}$. Another study (Elsyad et al.), which showed a survival rate of $93 \%$, did not report torque values during the implant insertion. Grandi et al. used an insertion torque of at least $40 \mathrm{Ncm}$ on 42 patients; in this study the survival rate was of $100 \%$ at one year of observation. Another study (Shayegh et al.), that reports a placement torque of the implants of more than $45 \mathrm{Ncm}$, obtained a survival of $100 \%$.

Another factor that must be considered to achieve a high implant survival is related to the skills of the surgeon and the expertise of the prosthodontist. In this case, the specialists were highly qualified.

Prosthetic assessment:

There are studies that have compared splinted implants and non-splinted implants. They suggest that there are no differences in clinical behavior of prostheses or implants (Payne \& Solomos, 2000; Heydenrijk et al., 2003). Turkylmaz (2006) citing other authors stated that the number of adjustments and repairs required for the maintenance of mandibular implant-supported overdentures are considerable and are usually needed within the first year. It also reported difficulties including fractures of the retentive gold caps, acrylic resin and denture teeth, as well as frequent reactivation of the retentive elements. This same author did not report statistically significant differences in the number of appointments for making an overdenture immediately loaded or loaded conventionally. There were also no statistically significant differences in the adjustment or repair of prostheses and in both types of load (Turkyilmaz et al.).

Schimmel et al. (2014) in a systematic review of the literature, says that when placing the overdenture the day of the surgery, the tissues are still traumatized and morphological changes will occur in the weeks following intervention. Therefore, relines will be necessary during the adaptive period. In this study, it was exceeded only 1 of 28 prostheses during a year of observation. Schimmel's study also states that immediate loading is necessary to make an impression when sutures are still at the surgical site and the material could contaminate the wound. In this study, the prostheses were previously manufactured and it was not necessary to take impressions in surgical sites that are still healing.

This study shows similarities with the results reported by Marzola et al., where minimal interventions on prostheses that cannot be attributable to the immediate loading of the prosthesis were needed. As in the study of Marzola, this research agrees that the use of ball adjustments allows for a very slight modification of the prosthesis compared to a design of bar and clip that needs more space to be adapted to 
ARISTIZABAL, H. J. A.; BURBANO, L. J. G.; SANDOVAL, R. A.; RAMíREZ, T. J. J.; CHACÓN, A. P. T.; GONZÁLEZ, O. S. \& ARANGO, G. C. E. Clinical and radiographic evaluation of rehabilitated implants with overdenture with two ball abutments in the mandible and submitted to immediate load: One year of observation. Int. J. Odontostomat., 11(4):451-459, 2017.

the prosthesis and consequently can weaken complete denture, so the risk of prosthesis fracture was reduced. Several studies (Shayegh et al.; Liao et al.; Kronstrom et al.; Roe et al., 2010) agree with this study that the most frequent maintenance on dentures was the need to replace the O-ring to improve retention.

Satisfaction: In this study, the overall patient satisfaction with treatment with the overdentures was high. Some studies have highlighted the satisfaction and quality of life of the patients with overdentures on two dental implants (Naert et al., 2004). This satisfaction is consistent with the findings of Naert et al., which concludes that the group with ball-retained overdenture had a high vertical retention and satisfaction with mandibular overdentures was similar for groups on nonsplinted and splinted implants.

\section{CONCLUSIONS}

After a year of observation, it can be concluded that the immediate loading of two non-splinted interforaminal implants in the mandible retaining an overdenture with ball abutments achieves high patient satisfaction and is a predictable treatment for edentulous patients that have a high survival rate of implants and a favorable response of the peri-implant tissues.

ARISTIZABAL, H. J. A.; BURBANO, L. J. G.; SANDOVAL, R. A.; RAMÍREZ, T. J. J.; CHACÓN, A. P. T.; GONZÁLEZ, O. S. \& ARANGO, G. C. E. Evaluación clínica y radiográfica de implantes rehabilitados con sobredentadura con dos pilares de bola en la mandíbula y sometidos a carga inmediata: Un año de observación. Int. J. Odontostomat., 11(4):451-459, 2017.

RESUMEN: El propósito de este estudio clínico prospectivo fue evaluar la supervivencia de manera clínica y radiográfica de dos implantes no ferulizados cargados inmediatamente con pilares tipo bola para soportar sobredentaduras mandibulares. Treinta pacientes desdentados totales usuarios de prótesis total (22 mujeres y 8 hombres) con una edad promedio de 64 años se incluyeron en este estudio. Cada paciente recibió dos implantes interforaminales en la mandíbula aproximadamente en posición de canino con un torque mayor a los $45 \mathrm{Ncm}$. Pilares no ferulizados tipo bola se conectaron a los implantes y se cargó inmediatamente la sobredentadura. El éxito de los implantes se evaluó clínica y radiográficamente; así como el nivel de satisfacción de los pacientes al año de haber sido colocados los implantes. Una paciente se retiró del estudio.
Después de 12 meses de cargados los implantes la tasa de supervivencia fue del $98,27 \%$, un implante fracasó. El promedio de pérdida ósea fue de $0.34 \mathrm{~mm}$. No se observaron complicaciones quirúrgicas, se requirieron citas de mantenimiento protésicas menores. La satisfacción de los pacientes fue del $89,3 \%$. La carga inmediata de dos implantes no ferulizados en el área interforaminal de la mandíbula reteniendo una sobredentadura a través de pilares en bola es un tratamiento predecible, con un alta tasa de éxito de supervivencia, y respuesta favorable de los tejidos periimplantares. Los pacientes muestran una buena satisfacción ante ésta modalidad de tratamiento.

PALABRAS CLAVE: carga inmediata del implante dental, sobre-dentadura, rehabilitación oral.

\section{REFERENCES}

Ahlqvist, J.; Borg, K.; Gunne, J.; Nilson, H.; Olsson, M. \& Astrand, P. Osseointegrated implants in edentulous jaws: a 2-year longitudinal study. Int. J. Oral Maxillofac. Implants, 5(2):155-63, 1990.

Albrektsson, T. Direct bone anchorage of dental implants. J. Prosthet. Dent., 50(2):255-61, 1983.

Alfadda, S. A.; Attard, N. J. \& David, L. A. Five-year clinical results of immediately loaded dental implants using mandibular overdentures. Int. J. Prosthodont., 22(4):36873, 2009.

Attard, N. J. \& Zarb, G. A. Immediate and early implant loading protocols: a literature review of clinical studies. J. Prosthet. Dent., 94(3):242-58, 2005.

Attard, N. J. \& Zarb, G. A. Long-term treatment outcomes in edentulous patients with implant overdentures: the Toronto study. Int. J. Prosthodont., 17(4):425-33, 2004.

Awad, M. A.; Lund, J. P.; Shapiro, S. H.; Locker, D.; Klemetti, E.; Chehade, A.; Savard, A. \& Feine, J. S. Oral health status and treatment satisfaction with mandibular implant overdentures and conventional dentures: a randomized clinical trial in a senior population. Int. J. Prosthodont., 16(4):390-6, 2003.

Babbush, C. A.; Kent, J. N. \& Misiek, D. J. Titanium plasmasprayed (TPS) screw implants for the reconstruction of the edentulous mandible. J. Oral Maxillofac. Surg., 44(4):274-82, 1986.

Bergendal, T. \& Engquist, B. Implant-supported overdentures: a longitudinal prospective study. Int. J. Oral Maxillofac. Implants, 13(2):253-62, 1998.

Brånemark, A.; Zarb, F. \& Albrektsson, B. Tissue Integrateprosthesis: Osseointegration in Clinical Dentistry. Chicago, Quintessence, 1985.

Buser, D. A.; Schroeder, A.; Sutter, F. \& Lang, N. The new concept of ITI hollow-cylinder and hollow-screw implants: Part 2. Clinical aspects, indications, and early clinical results. Int. J. Oral Maxillofac. Implants, 3(3):173-81, 1988.

Cehreli, M. C.; Uysal, S. \& Akca, K. Marginal bone level changes and prosthetic maintenance of mandibular 
ARISTIZABAL, H. J. A.; BURBANO, L. J. G.; SANDOVAL, R. A.; RAMíREZ, T. J. J.; CHACÓN, A. P. T.; GONZÁLEZ, O. S. \& ARANGO, G. C. E. Clinical and radiographic evaluation of rehabilitated implants with overdenture with two ball abutments in the mandible and submitted to immediate load: One year of observation. Int. J. Odontostomat., 11(4):451-459, 2017.

overdentures supported by 2 implants: a 5-year randomized clinical trial. Clin. Implant Dent. Relat. Res., 12(2):114-21, 2010.

Degidi, M. \& Piattelli, A. Comparative analysis study of 702 dental implants subjected to immediate functional loading and immediate nonfunctional loading to traditional healing periods with a follow-up of up to 24 months. Int. J. Oral Maxillofac. Implants, 20(1):99-107, 2005.

Elsyad, M. A.; Al-Mahdy, Y. \& Fouad, M. M. Marginal bone loss adjacent to conventional and immediate loaded two implants supporting a ball-retained mandibular overdenture: a 3-year randomized clinical trial. Clin. Oral Implants Res., 23(4):496-503, 2012.

Esposito, M.; Grusovin, M. G.; Willings, M.; Coulthard, P. \& Worthington, H. V. The effectiveness of immediate, early, and conventional loading of dental implants: a Cochrane systematic review of randomized controlled clinical trials. Int. J. Oral Maxillofac. Implants, 22(6):893-904, 2007.

Feine, J. \& Carlsson, G. Implant Overdentures: The Standard of Care for Edentulous Patients. Chicago, Quintessence Publishing, 2003.

Feine, J. S.; Carlsson, G. E.; Awad, M. A.; Chehade, A.; Duncan, W. J.; Gizani, S.; Head, T.; Heydecke, G.; Lund, J. P.; MacEntee, M.; Mericske-Stern, R.; Mojon, P.; Morais, J. A.; Naert, I.; Payne, A. G.; Penrod, J.; Stoker, G. T.; Tawse-Smith, A.; Taylor, T. D.; Thomason, J. M.; Thomson, W. M. \& Wismeijer, D. The McGill consensus statement on overdentures. Mandibular two-implant overdentures as first choice standard of care for edentulous patients. Gerodontology, 19(1):3-4, 2002.

Gatti, C.; Haefliger, W. \& Chiapasco, M. Implant-retained mandibular overdentures with immediate loading: a prospective study of ITI implants. Int. J. Oral Maxillofac. Implants, 15(3):383-8, 2000.

Grandi, T.; Guazzi, P.; Samarani, R.; Garuti, G. \& Grandi, G. Immediate loading of two unsplinted implants retaining the existing complete mandibular denture in elderly edentulous patients: 1-year results from a multicentre prospective cohort study. Eur. J. Oral Implantol., 5(1):618, 2012.

Heydenrijk, K.; Raghoebar, G. M.; Meijer, H. J. A. \& Stegenga, $B$. Clinical and radiologic evaluation of 2-stage IMZ implants placed in a single-stage procedure: 2-year results of a prospective comparative study. Int. J. Oral Maxillofac. Implants, 18(3):424-32, 2003.

Hobo, S.; Ichida, E. \& Garcia, L. Osseointegration and Occlusal Rehabilitation. Tokyo, Quintessence, 1989.

Johns, R. The role of osseointegrated dental implants in the treatment of elderly people. Dent. Update, 17(1):19-23, 1990.

Kawai, Y. \& Taylor, J. A. Effect of loading time on the success of complete mandibular titanium implant retained overdentures: a systematic review. Clin. Oral Implants Res., 18(4):399-408, 2007.

Kronstrom, M.; Davis, B.; Loney, R.; Gerrow, J. \& Hollender, $\mathrm{L}$. A prospective randomized study on the immediate loading of mandibular overdentures supported by one or two implants: a 12-month follow-up report. Int. J. Oral Maxillofac. Implants, 25(1):181-8, 2010.
Lachmann, S.; Kimmerle-Müller, E.; Gehring, K.; Axmann, D.; Gomez-Roman, G.; Watzek, G. \& Weber, H. A comparison of implant-supported, bar- or ball-retained mandibular overdentures: a retrospective clinical, microbiologic, and immunologic study of 10 edentulous patients attending a recall visit. Int. J. Prosthodont., 20(1):37-42, 2007.

Lahori, M.; Kaul, A. S.; Chandra, S.; Nagrath, R. \& Gupta, H. A comparative evaluation of crestal bone levels in mandibular implant-retained overdentures using delayed and immediate loading protocols: An in vivo study. Int. J. Oral Implantol. Clin. Res., 3(1):1-7, 2012.

Liao, K. Y.; Kan, J. Y.; Rungcharassaeng, K.; Lozada, J. L.; Herford, A. S. \& Goodacre, C. J. Immediate loading of two freestanding implants retaining a mandibular overdenture: 1-year pilot prospective study. Int. J. Oral Maxillofac. Implants, 25(4):784-90, 2010.

Liddelow, G. \& Henry, P. The immediately loaded single implant-retained mandibular overdenture: a 36-month prospective study. Int. J. Prosthodont., 23(1):13-21, 2010.

Liddelow, G. J. \& Henry, P. J. A prospective study of immediately loaded single implant-retained mandibular overdentures: preliminary one-year results. J. Prosthet. Dent., 97(6 Suppl.):S126-137, 2007.

Marzola, R.; Scotti, R.; Fazi, G. \& Schincaglia, G. Immediate loading of two implants supporting a ball attachmentretained mandibular overdenture: a prospective clinical study. Clin. Implant Dent. Relat. Res., 9(3):136-43, 2007.

Meredith, N. Assessment of implant stability as a prognostic determinant. Int. J. Prosthodont., 11(5):491-501, 1998.

Mericske-Stern, R. \& Zarb, G. A. Overdentures: an alternative implant methodology for edentulous patients. Int. J. Prosthodont., 6(2):203-8, 1993.

Mericske-Stern, R. Clinical evaluation of overdenture restorations supported by osseointegrated titanium implants: a retrospective study. Int. J. Oral Maxillofac. Implants, 5(4):375-83, 1990.

Mombelli, A. \& Lang, N. P. Clinical parameters for the evaluation of dental implants. Periodontology 2000, 4:816, 1994.

Naert, I.; Alsaadi, G. \& Quirynen, M. Prosthetic aspects and patient satisfaction with two-implant-retained mandibular overdentures: a 10-year randomized clinical study. Int. J. Prosthodont., 17(4):401-10, 2004.

Payne, A. G. \& Solomons, Y. F. Mandibular implant-supported overdentures: a prospective evaluation of the burden of prosthodontic maintenance with 3 different attachment systems. Int. J. Prosthodont., 13(3):246-53, 2000.

Roe, P.; Kan, J. Y.; Rungcharassaeng, K. \& Lozada, J. Immediate loading of unsplinted implants in the anterior mandible for overdentures: 3-year results. Int. J. Oral Maxillofac. Implants, 26(6):1296-302, 2011.

Roe, P.; Kan, J. Y.; Rungcharassaeng, K.; Lozada, J. L.; Kleinman, A.; Goodacre, C. \& Chen, J. W. Immediate loading of unsplinted implants in the anterior mandible for overdentures: a case series. Int. J. Oral Maxillofac. Implants, 25(5):1028-35, 2010.

Romeo, E.; Chiapasco, M.; Lazza, A.; Casentini, P.; Ghisolfi, M.; Iorio, M. \& Vogel, G. Implant-retained mandibular 
ARISTIZABAL, H. J. A.; BURBANO, L. J. G.; SANDOVAL, R. A.; RAMÍREZ, T. J. J.; CHACóN, A. P. T.; GonZÁLEZ, O. S. \& ARANGO, G. C. E. Clinical and radiographic evaluation

overdentures with ITI implants. Clin. Oral Implants Res., 13(5):495-501, 2002.

Shayegh, S.; Semyari, H.; Shahraki, A. \& Hakimaneh, M. Implant-retained mandibular overdentures: a comparative study of immediate loading vs delayed loading after one year. Int. J. Oral Implantol. Clin. Res., 3(3):105-10, 2012.

Stoker, G.; Wismeijer, D. \& van Waas, M. A. An eight-year follow-up to a randomized clinical trial of aftercare and cost-analysis with three types of mandibular implantretained overdentures. J. Dent. Res., 86(3):276-80, 2007.

Stricker, A.; Gutwald, R.; Schmelzeisen, R. \& Gellrich, N. G. Immediate loading of 2 interforaminal dental implants supporting an overdenture: clinical and radiographic results after 24 months. Int. J. Oral Maxillofac. Implants, 19(6):868-72, 2004.

Thomason, J. M.; Feine, J.; Exley, C.; Moynihan, P.; Müller, F.; Naert, I.; Ellis, J. S.; Barclay, C.; Butterworth, C.; Scott, B.; Lynch, C.; Stewardson, D.; Smith, P.; Welfare, R.; Hyde, P.; McAndrew, R.; Fenlon, M.; Barclay, S. \& Barker, D. Mandibular two implant-supported overdentures as the first choice standard of care for edentulous patients--the York Consensus Statement. Br. Dent. J., 207(4):185-6, 2009.

Tokuhisa, M.; Matsushita, Y. \& Koyano, K. In vitro study of a mandibular implant overdenture retained with ball, magnet, or bar attachments: comparison of load transfer and denture stability. Int. J. Prosthodont., 16(2):128-34, 2003.

Turkyilmaz, I.; Tozum, T. F.; Fuhrmann, D. M. \& Tumer, C. Seven-year follow-up results of TiUnite implants supporting mandibular overdentures: early versus delayed loading. Clin. Implant Dent. Relat. Res., 14 Suppl., 1:e8390, 2012.

Turkyilmaz, I.; Tumer, C.; Avci, M.; Hersek, N. \& Celik-Bagci, E. A short-term clinical trial on selected outcomes for immediately loaded implant-supported mandibular overdentures. Int. J. Prosthodont., 19(5):515-9, 2006.

van Kampen, F.; Cune, M.; van der Bilt, A. \& Bosman, F. Retention and postinsertion maintenance of bar-clip, ball and magnet attachments in mandibular implant overdenture treatment: an in vivo comparison after 3 months of function. Clin. Oral Implants Res., 14(6):7206, 2003.

\author{
Corresponding author: \\ Dr. Juan Alberto Aristizabal Hoyos \\ Universidad Autónoma de Manizales \\ Antigua Estación del Ferrocarril Manizales \\ COLOMBIA
}

Email: jaristi@autonoma.edu.co

Received: 12-07-2017

Accepted: 13-09-2017 